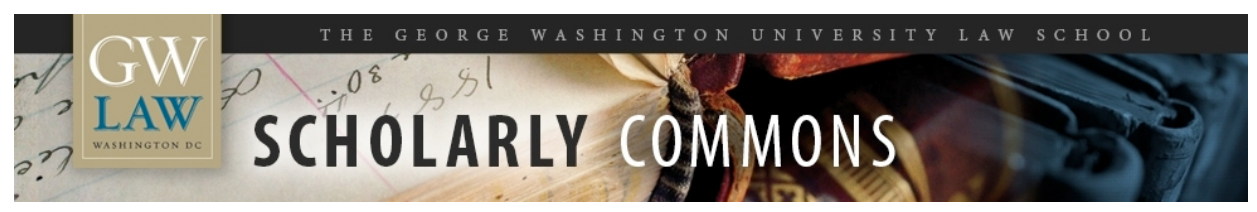

\title{
Ruth Bader Ginsburg and the Interaction of Legal Systems
}

\author{
Paul Schiff Berman \\ George Washington University Law School, pberman@law.gwu.edu
}

Follow this and additional works at: https://scholarship.law.gwu.edu/faculty_publications

Part of the Law Commons

\section{Recommended Citation}

Berman, Paul Schiff, Ruth Bader Ginsburg and the Interaction of Legal Systems (2015). The Legacy of Ruth Bader Ginsburg, Scott Dodson, ed., Cambridge Univ. Press, 2015; GWU Law School Public Law Research Paper No. 2015-19; GWU Legal Studies Research Paper No. 2015-19. Available at SSRN:http://ssrn.com/abstract=2605824

This Book Part is brought to you for free and open access by the Faculty Scholarship at Scholarly Commons. It has been accepted for inclusion in GW Law Faculty Publications \& Other Works by an authorized administrator of Scholarly Commons. For more information, please contact spagel@law.gwu.edu. 


\title{
The Legacy of Ruth Bader Ginsburg
}

\author{
Edited by \\ SCOTT DODSON \\ University of California Hastings College of the Law
}




\title{
Ruth Bader Ginsburg and the Interaction of Legal Systems
}

\author{
Paul Schiff Berman
}

From her early days writing a book on Civil Procedure in Sweden,' to her time as law professor, judge, and justice, Ruth Bader Ginsburg has always been acutely sensitive to the fact that legal systems are not hermetically sealed from each other. Always there must be ways of negdtiating the interactions among such systems. In the United States, of course, such interactions often involve navigating a federalist structure of fifty-one different sovereignties, in addition to tribal governments. Internationally, the interaction of legal systems may involve the degree to which U.S. constitutional norms govern U.S. officials abroad, the impact of foreign judgments in the United States, and the potential influence of international or transnational law in domestic cases.

This chapter begins with some general observations about the reality of this legal pluralism and various possible approaches to the systemic interactions that inevitably result. Then, it surveys some of Ginsburg's key writings on the interaction of legal systems, both in law journals and in judicial opinions. This analysis reveals a consistent theme in Ginsburg's jurisprudence. Across a variety of substantive legal areas, Ginsburg often chooses a path that provides maximum play among the legal systems at issue. Beginning with her earliest scholarly writings, she has tended to oppose doctrines allowing one legal system to block another from adjudicating a dispute, and throughout her later career Ginsburg likewise tends to reject bright-line rules that choose one legal system over another. Instead, she often seems to prefer procedural arrangements that seek accommodation and flexibility in order to ensure that multiple legal systems and a variety of norms and processes are respected. These principles also carry over to Ginsburg's views about international and transnational law. A committed internationalist, Ginsburg advocates the importance 
of seeking wisdom from others. This nondogmatic, deferential approach to plural legal systems characterizes much of her jurisprudence on intersystemic conflicts, though interestingly such deference does not always apply with a s much force in Ginsburg's opinions concerning tribal communities. By taking stock of Ginsburg's navigation of legal pluralism in a set of representative writings, we can better theorize her contribution to a jurisprudential approach that seeks ongoing negotiation in an interlocking world of multiple jurisdictions and multiple legal norms.

\section{POTENTIAL STRATEGIES FOR RESPONDING TO}

LEGAL PLURALISM

Law often operates based on the convenient fiction that human activity is only subject to the rules of one legal system at a time. Yet jurisdictional overlap is unavoidable, and so, inevitably, law must negotiate situations when multiple communities and legal authorities seek to regulate the same act or actor. Scholars studying interactions among these multiple communities have often used the term "legal pluralism" to describe the intermingling of these normative systems. ${ }^{2}$

The study of plural normative systems has arisen from a variety of different scholarly traditions. Perhaps the earliest studies of the clashes between state and nonstate authority were those penned by lawyers, philosophers, and theologians interested in the respective realms of church and state. ${ }^{3}$ Likewise, historians analyzing the regulatory role of nonstate entities such as jockey clubs and stock exchanges noted that these entities often wield more power than formal state law. ${ }^{4}$ For their part, anthropologists used the idea of legal pluralism to conceptualize the relationship between colonial and indigenous legal systems. ${ }^{5}$ And social norms theorists and scholars in behavioral law and economics have become interested in forms of informal law that often regulate behavior as much as, or more than, official governmental pronouncements. ${ }^{6}$

Although legal pluralism was originally a way to broaden the scholarly lens to study the interaction between state and nonstate law, in recent years the insights of legal pluralism have also been used to analyze the more traditional interactions among formal legal systems both internationally and within one nation-state. ${ }^{7}$ In the years following the collapse of the bipolar Cold War order, it became clear that the traditional framework of international law had expanded to include jurisdictional overlaps among many different courts, tribunals, panels, and arbitral bodies. Legal pluralism became a helpful way to analyze these complex relationships, which often lack explicit hierarchies. And even within domestic federal systems, the intersystemic interactions 
among states and between state and national sovereigns created fertile ground for studying pluralism in action. ${ }^{8}$

So, how should law respond to the reality of multiple overlapping legal systems? Often, these hybrid legal spaces have been viewed simply as a problem to be solved. This is perhaps why the possibility that parties might engage in forum shopping is so often referenced pejoratively. Thus, even when jurisdictional overlap or regulatory interdependence is undeniable, we see what Robert Ahdieh has termed "the standard dualist response." Law seeks to delimit each entity's jurisdiction and authority more effectively and thereby eliminate such overlap. This paradigm of jurisdictional line drawing has been prevalent both in the international/transnational realm ${ }^{10}$ and in discussions of federalism," as courts and scholars try to demarcate distinct spheres for state and federal authority. As Ahdieh notes, "Such reactions are hardly surprising. At heart, they reflect some visceral sense of law's project as one of categorization, clear definition, and line-drawing."

Yet this single-minded focus on certainty and clarity not only fails to describe a globalized world of inevitable cross-border jurisdictional overlap but also ignores the crucial question of whether leaving open space for such overlapping regulatory authority might actually be beneficial. Indeed, while jurisdictional overlap is frequently viewed as a problem because it potentially creates conflicting obligations and uncertainty, we might also view jurisdictional redundancy as a necessary adaptive feature of a multivariate, pluralist legal system. The very existence of overlapping jurisdictional claims often leads to a nuanced negotiation - either explicit or implicit - between or among the various communities making those claims. ${ }^{13}$

In focusing on the pluralist opportunities inherent in jurisdictional overlap, I echo the insights of Robert Cover's article "The Uses of Jurisdictional Redundancy." 14 Cover analyzed American federalism and celebrated the benefits that accrue from having multiple overlapping jurisdictional assertions. Such benefits include a greater possibility for error correction, a more robust field for norm articulation, and a larger space for creative innovation..$^{15}$ Moreover, when decision makers are forced to consider the existence of other possible decision makers, they may tend to adopt, over time, a more restrained view of their own power and come to see themselves as part of a larger tapestry of decision making in which they are not the only potentially relevant voice. Finally, though Cover acknowledged that it might seem perverse "to seek out a messy and indeterminate end to conflicts which may be tied neatly together by a single authoritative verdict," he nevertheless argued that we should "embrace" a system "that permits tensions and conflicts of the social order" to be played out in the jurisdictional structure of the system. ${ }^{16}$ More recently, 
Judith Resnik has noted the "multiple ports of entry" that a federalist system creates $^{17}$ and has argued that what constitutes the appropriate spheres for "local," "national," and "international" regulation and adjudication changes over time and should not be essentialized. ${ }^{18}$

Building on these principles, we can perhaps identify two different strategies for responding to legal pluralism. On the one hand, judges facing an issue of intersystemic complexity can seek to bring order by engaging in linedrawing and delimiting separate spheres of authority. This is what Cover calls a "jurispathic" approach because it necessarily requires the decision maker to anoint one jurisdiction as the legitimate authority and decree that all other jurisdictions are disabled from applying their norms. In doing so, the decision maker "kills off" conflicting interpretations and authorities. ${ }^{19}$ The contrasting approach is what Cover would call "jurisgenerative." ${ }^{\text {" To }}$ This pluralist approach seeks modes of accommodation, deference, and hybridity that will allow multiple jurisdictions to continue to speak to a particular legal problem, without blocking the dialogue among systems. ${ }^{21}$ Thus, the pluralist framework provides a way of analyzing jurisprudence concerning the interaction of legal systems in terms of whether it preserves or cuts off intersystemic dialogue. This framework also reveals patterns in Justice Ginsburg's jurisprudence across a variety of substantive legal areas.

\section{POLICING COURT RULINGS THAT INTERFERE WITH THE PROCESSES OF OTHER COURTS}

From the beginning of her scholarly career, Ginsburg was clearly interested in questions of intersystemic interaction and particularly the concern that one authority might cut off the ability of another authority to effectively hear a case. Indeed, one of her first major law review articles focused largely on the problem of antisuit injunctions. Entitled "Judgments in Search of Full Faith and Credit: The Last-in-Time Rule for Conflicting Judgments," ${ }^{22}$ Ginsburg considered in this article what should happen when a court in one state enjoins parties before it from proceeding in a lawsuit in another state. In particular, she asked whether such antisuit injunctions should receive full faith and credit in the second state, thereby blocking the litigation process in that state.

After noting the U.S. Supreme Court's silence on this issue, Ginsburg set forth the two extreme possible options in response. First, one might view the Full Faith and Credit Clause of the U.S. Constitution ${ }^{23}$ as such an exacting command that even an antisuit injunction must be respected by the second court. Ginsburg suggested that such a rule would be "consistent with the generally strict line the Supreme Court has taken on full faith and credit to 
judgments," but she also observed that "state courts on the receiving end of such injunctions have not found this a palatable solution." 24 Second, there could be "a general rule denying the states authority to issue injunctions directed at proceedings in other states." ${ }^{25}$ Although such a rule would protect the interests of the second court in pursuing its judicial process, the rule would disable the first court from issuing the relief sought by one of the parties. Thus, either option seems jurispathic, cutting off the legal process of one or the other of the courts at issue.

Significantly, Ginsburg rejected both of these jurispathic options and argued in favor of a middle ground approach: "permitting the injunction to issue but not compelling any deference outside the rendering state." ${ }^{26}$ Thus, the initial court could still issue the injunction, but such an injunction would not be binding on the second court. Instead, the injunction might be accorded respect (and enforcement) by the second court, but only "as a matter of comity." ${ }^{27}$

Given how much this article foreshadows Ginsburg's later jurisprudence, it is worth pausing to consider her solution to the problem of antisuit injunctions. Neither court ends up wielding absolute authority independent of the other; neither court fully' silences the other. Although the second court seems on the surface to retain the ultimate power to accept or reject the first court's injunction, such power cannot be wielded without significant cost because, under Ginsburg's approach, the second court would lose credibility and legitimacy if it rejected the first court's injunction without at least addressing the first court's reasoning. Thus, even if the second court retains ultimate authority, it must engage the first court's views before wielding jurispathic power. This built-in intersystemic dialogue - whereby one court asks another to refrain from litigation, and the other court then must decide how much it can defer to the first court's order - respects both courts as adjudicatory actors and leaves resolution of individual cases to a dialogic and dialectical process among courts exercising restraint, deference, and comity.

As a justice, Ginsburg has taken a similar approach to the Full Faith and Credit Clause in two U.S. Supreme Court cases. First, in Matsushita Electric Industries Co. v. Epstein ${ }^{28}$ the Court considered whether a Delaware classaction settlement should preclude litigation in a California federal court pursued by class members who argued that they were not adequately represented in Delaware. Although the Court granted preclusive effect to the Delaware settlement, thereby blocking the California litigation, Ginsburg dissented in relevant part. Ginsburg argued that the Full Faith and Credit Clause should not automatically bar the California litigation, especially given the assertion that the lawyers in Delaware did not represent the interests of all 
class members. ${ }^{29}$ Indeed, she suggested that in this case the attorneys for the class may have too easily relinquished the class's rights to pursue the federal litigation in order to pocket their attorneys' fees. $3^{\circ}$ Accordingly, due process, Ginsburg argued, required an inquiry regarding the adequacy of class representation in the first litigation before the second litigation should be blocked by full faith and credit. ${ }^{31}$ Thus, although preclusion doctrine is somewhat different from the antisuit injunctions discussed in her earlier article, Ginsburg similarly rejected automatic enforcement of an injunction that would have the effect of blocking litigation elsewhere.

Two years later, in Bakerv. General Motors Corp., ${ }^{32}$ Ginsburg returned to the realm of antisuit injunctions (even citing her own early law review article) ${ }^{33}$ and commanded a majority for her view regarding the proper operation of the Full Faith and Credit Clause when one court's order aims to block the operation of a second court's judicial process. Baker concerned a stipulated injunction submitted to and signed by a Michigan court in settlement of a lawsuit between General Motors (GM) and Ronald Elwell, a former GM employee. ${ }^{4}$ Among other terms, the stipulated injunction purported to prevent Elwell from testifying against GM in subsequent legal proceedings. 35 The question posed before the Supreme Court was whether, in a separate wrongful death suit brought in a Missouri federal court by the Bakers against GM, Elwell could be called as a plaintiff's witness or whether instead the Michigan injunction blocked Elwell from testifying. And while it was clear that the Michigan judgment could not preclude the Bakers, who were not parties to the Michigan proceedings, the difficult question was whether it could bind Elwell, who obviously had been a party in Michigan, and therefore keep him from testifying. ${ }^{36}$ The Missouri federal district court judge ruled that allowing such a result would run counter to public policy and therefore invoked a public policy exception to the Full Faith and Credit Clause, whereby rendering courts would be free to ignore prior court judgments' anathema to the rendering court's local policies. ${ }^{37}$

Thus, the Supreme Court appeared to be faced with a binary choice. On the one hand, the Court could endorse the Missouri District Court's ruling and allow courts to extricate themselves from the Full Faith and Credit Clause simply by deeming a sister jurisdiction's judgment contrary to public policy. On the other hand, the Court could enforce the Michigan court's order, thereby allowing Michigan's ruling to prevent any other court in the country from hearing Elwell's testimony in cases against GM.

Not surprisingly, as with the antisuit injunctions discussed in her article, Ginsburg rejected both of these jurispathic options. Writing for the Court, she first made it clear that although choice-of-law doctrines permit courts to use public policy objections in choosing the law to apply in a cross-jurisdictional 
case, the command of the Full Faith and Credit Clause with regard to prior judgments is far more "exacting" and permits no such set of broad exceptions: "A final judgment in one State, if rendered by a court with adjudicatory authority over the subject matter and persons governed by the judgment, qualifies for recognition throughout the land." $3^{8}$ Thus, the Missouri court could not simply ignore the Michigan judgment based on assertions of public policy.

At the same time, the Michigan court could not automatically block the adjudication in Missouri. "Michigan's judgment," she wrote, "cannot reach beyond the Elwell-GM controversy to control proceedings againstGM brought in other States, by other parties, asserting claims the merits of which Michigan has not considered." 39 The problem with the Michigan order, according to Ginsburg, was that "Michigan lacks authority to control courts elsewhere by precluding them, in actions brought by strangers to the Michigan litigation, from determining for themselves what witnesses are competent to testify and what evidence is relevant and admissible in their search for the truth."40

Thus, Ginsburg aimed to maintain a system in which courts respect each other's authority and judgments. Michigan's judgment could not silence Missouri in matters that Missouri had a right to adjudicate, just as Missouri could not simply ignore a lawful Michigan judgment by interposing local public policy concerns. A Full Faith and Credit Clause without a public policy exception helps ensure an interlocking system of justice whereby parties cannot evade legal judgments simply by fleeing the jurisdiction. But at the same time, Ginsburg called on courts to be restrained in the kinds of judgments they issue, remaining mindful of the prerogatives of other courts to pursue their own proceedings unfettered by foreign judgments. As a result, both the need for interdependence and independence within a federalist court system can be maintained. Her decision therefore preserves pluralist, intersystemic interaction.

Ginsburg reached a similar result in Marshall v. Marshall,"+ when, writing for the Court, she clarified that no broad exception to traditional jurisdictional rules should allow a state probate-court decision to divest federal bankruptcy courts of jurisdiction in a case involving claims related to an inheritance dispute. As in Matsushita and Baker, Ginsburg rejected the idea that an exercise of power by one court should be transformed into a broad assertion of exclusive power that would prevent other courts from litigating issues over which they would otherwise have jurisdiction. Instead, though she acknowledged that a probate court, once it exercised jurisdiction over the assets of an estate might retain exclusive jurisdiction over the distribution of those assets, she limited the scope of exclusivity only to the administration of a decedent's estate..$^{42}$ The probate court could not, she wrote, "bar federal courts from adjudicating matters outside those confines and otherwise within federal jurisdiction." 43 
In each of these instances Ginsburg opted to establish and preserve spaces of concurrent jurisdiction among multiple courts, neither foreclosing courts from speaking to issues before them, nor permitting them to foreclose subsequent courts from litigating related matters on their own. The danger, according to Ginsburg's jurisprudence, lies in decisions that usurp power over the judicial processes of other courts. Instead, these opinions suggest that mutual voice, restraint, deference, and comity are more the touchstones of her judicial vision.

\section{NAVIGATING FEDERALISM}

These same principles of deference carry over to areas of federalism, where Justice Ginsburg has often shown her willingness to defer to state prerogatives in interpreting state law. This deference may surprise those who focus on Justice Ginsburg's Fourteenth Amendment jurisprudence in gender-related cases. Certainly, Ginsburg supports a muscular interpretation of federal constitutional rights. After all, her most prominent pre-judicial role was as the head of the Women's Rights Project of the American Civil Liberties Union."H And of course her forceful advocacy in the 1970 \$ $^{45}$ (as well as her own decision for the Supreme Court in United States $v$. Virginia) ${ }^{46}$ has helped establish gender as a category for heightened scrutiny in equal-protection analysis.

Yet, though she is clearly' a strong advocate for protecting federal rights, Ginsburg is often likely to seek ways to defer to and accommodate state interests to the extent possible. Indeed, she is far more deferential to the prerogatives of states than one might expect if one focused only on the gender cases.47 This section first surveys four dissents in which Ginsburg argued against federal intrusion into traditional state-law domains. Then, it turns to three cases either applying the so-called Erie doctrine or federal preemption doctrine, two areas where courts are asked to negotiate the fault lines between state and federal law. These cases show Ginsburg seeking creative ways to effectuate both state and federal interests to the extent possible.

\section{A. Deference to State Law Domains}

In the 1994 case of Honda Motor Co. v. Oberg, the Supreme Court considered a provision of the Oregon Constitution prohibiting judicial review of the amount of punitive damages awarded by a jury "unless the court can affirmatively say there is no evidence to support the verdict." $4^{8}$ The Court ruled that such a provision violated the Due Process Clause of the federal constitution. ${ }^{49}$ Justice Ginsburg dissented, focusing on the variety of ways in which 
Oregon statutory law already protected against excessive punitive-damage awards. In particular, Ginsburg noted that under Oregon law, the plaintiff in product-liability cases must prove by "clear and convincing evidence" that the defendant "show[ed] wanton disregard for the health, safety and welfare of others." 50 Moreover, the statute set forth seven substantive criteria to cabin the discretion of the factfinder. ${ }^{51}$ And Oregon permitted judges to overturn a jury punitive-damages award "if reversible error occurred during the trial, if the jury was improperly or inadequately instructed, or if there is no evidence to support the verdict." ${ }^{2}$ Given these protections, Ginsburg saw no reason for federal Due Process concerns to trump the Oregon constitutional provision forbidding general reexamination of a jury's punitive-damage awards. 53

Four years later, Ginsburg again dissented from a Supreme Court decision overturning a state-law punitive-damages verdict. In $B M W v$. Gore, the Court found an Alabama jury award "grossly excessive," in violation of the Fourteenth Amendment's Due Process Clause.54 Ginsburg, in contrast, argued that the award should be policed by the Alabama courts and that the U.S. Supreme Court should "resist unnecessary intrusion into an area dominantly of state concern." 55 Significantly, Ginsburg's dissent rested on two core arguments. First, she suggested that the-Court should defer to the Alabama Supreme Court, which "report[ed] that it "thoroughly and painstakingly" reviewed the jury's award according to federal due process criteria..$^{56}$ According to Ginsburg, this judgment was entitled to a "presumption of legitimacy," 57 and the U.S. Supreme Court should not "be quick to find a constitutional infirmity." 8 Second, she noted that by entering this traditional state domain with a constitutional ruling binding on all the states, the U.S. Supreme Court would be deprived of the wisdom that comes from having multiple courts develop jurisprudence in concert. 59 Indeed, she contrasted the Court's new punitivedamages review process with what typically occurs in habeas corpus review under 28 U.S.C. $\int 2254{ }^{60}$ In contrast to such habeas cases, Ginsburg pointed out, the Court, when reviewing punitive-damages verdicts under Gore, "will work at this business alone. It will not be aided by the federal district courts and courts of appeals. It will be the only federal court policing the area." ${ }_{1}$ Thus, by refusing to defer to states and by building its own ad hoc review process, Ginsburg opined, the Supreme Court would be left to review damage awards with neither the potential guidance of the state courts nor the potential wisdom of other federal courts. In short, she objected to the hierarchical lack of pluralism in the emerging jurisprudence.

Ginsburg has argued for greater deference to state processes in other contexts as well. City of Chicago v. International College of Surgeons ${ }^{62}$ began as a case involving state court review of a municipal agency's denial of demolition 
permits. Such review is generally deferential under state law, limited to whether there was adequate evidence in the record to support the agency's discretionary judgment. ${ }^{{ }_{3}}$ Nevertheless, the Court permitted federal courts to exercise supplemental jurisdiction - and possibly full de novo review - over such claims if appended to other federal claims. ${ }^{64}$ While acknowledging that the "bare words" of the federal jurisdictional statute permit the exercise of jurisdiction in such cases, ${ }^{65}$ Ginsburg dissented, arguing that the statute should not be read to extend federal jurisdiction over these sorts of state appellate reviews of state agency decisions. ${ }^{66}$ According to Ginsburg, permitting such "cross-system appeals" would trench on areas traditionally within state authority. ${ }^{67}$ She criticized the majority for "displac[ing] state courts as forums for on-the-record review of state and local agency actions." ${ }^{68}$ And she worried that "after today, litigants asserting federal-question or diversity jurisdiction may routinely lodge in federal courts direct appeals from the actions of all manner of local (county and municipal) agencies, boards, and commissions. Fxercising this cross-system appellate authority, federal courts may now directly superintend local agencies by affirming, reversing, or modifying their administrative rulings." ${ }^{\text {g9 }}$

One could imagine an even môre pluralist approach than Ginsburg's. For example, the Court might have permitted federal jurisdiction but incorporated the state standard of deferential review. Alternatively, the Court might have developed a form of abstention doctrine that allows federal courts to proceed but only after allowing state courts first crack at resolving the issue. However, both of these avenues would be complicated given the language of the jurisdiction statute. Thus, Ginsburg's position probably goes as far as she could: denying federal supplemental jurisdiction over such claims but allowing the exercise of that authority to be checked by federal constitutional review, thereby preserving intersystemic dialogue. In contrast, the interpretation of the jurisdictional statute adopted by the majority allows the federal court to function as a fully independent alternative appellate forum in diversity cases, one that could trump state practices and standards of review.

This same concern for preserving the states' ability to interpret their own laws carries over to Ginsburg's long-held opposition to the Supreme Court's 1983 decision in Michigan v. Long. ${ }^{\circ}$ In Long, the Court held that in criminal cases, when it is unclear whether a state-court decision rests on state or federal law, the federal court will assume that the state court relied on federal law, thereby subjecting the state-court decision to federal review..$^{71}$ This presumption, according to Ginsburg, gets it backward. Although she was not on the Court when Long was decided, ${ }^{72}$ in a subsequent dissent she wrote: "The Long presumption, as I see it, impedes the States' ability to serve as laboratories for 
testing solutions to novel legal problems." 73 Instead, she argued that "this Court should select a jurisdictional presumption that encourages States to explore different means to secure respect for individual rights in modern times."74

In all four of these dissents, Ginsburg is concerned that federal courts are inappropriately displacing the ability of states to have voice regarding matters of traditional state dominion. However, that does not mean that Ginsburg always simply opts for greater state autonomy in every case. For example, she joined the dissents in both United States v. Lopez ${ }^{75}$ and United States v. Morrison, ${ }^{76}$ in which the Court curtailed Congress's Commerce Clause power. And of course, she has long advocated more robust federal enforcement of constitutional equal protection norms in gender discrimination cases. Thus, it might be more appropriate to view Ginsburg as a cooperative or dialogic federalist rather than a separate-spheres federalist. 77 She seems most concerned with giving states voice in a multisystem conversation rather than displacing federal authority altogether.

\section{B. Solomonic Effectuation of Plural Interests}

This emphasis on accommodating both state and federal authority is most easy to see in those cases in which Ginsburg has explicitly sought to effectuate both sets of interests simultaneously. As noted previously, many of the doctrines aimed at navigating the relative domains of state and federal sovereignty are built on binary decision making and clear lines of demarcation. Either a case is within state jurisdiction or federal; either state law or federal law applies, and so on. But Ginsburg tends to favor overlapping jurisdictional schemes and more deferential accommodation of multiple interests. In the three cases that follow, she works mightily to achieve this sort of pluralist resolution, even when the path for doing so is less than obvious.

The first is Gasperini v. Center for Humanities, Inc..$^{8}$ Here, the Court continued a line of cases considering when a federal court hearing a state claim should apply state or federal law. Ever since the Court's landmark decision in Erie Railroad v. Tompkins, federal courts hearing state claims are required to apply state substantive law, essentially as if the case were being decided in a state court.79 But what happens if applying the state law conflicts with the rules governing the general operation of federal courts? These are some of the knotty problems in what has become known as the Erie doctrine.

Gasperini presented a particularly difficult application of the doctrine because both the state and federal interests at stake were so strong. New York had passed a tort-reform statute that sought to rein in what were perceived to be excessive jury awards. ${ }^{80}$ Under the statute, state appellate courts were 
empowered to review the size of jury verdicts and to order new trials whenever the jury's award "deviates materially from what would be reasonable compensation." ${ }^{\text {1 }}$ Thus, it would seem that if such a situation happened to arise in a state-law case brought in federal court, the federal appellate court should, pursuant to Erie and its progeny, apply the New York law allowing appellate reexamination of the jury verdict. However, under the Seventh Amendment of the U.S. Constitution, which governs proceedings in federal court but not in state court, "the right of trial by jury shall be preserved, and no fact tried by a jury, shall be otherwise re-examined in any Court of the United States, than according to the rules of the common law." ${ }^{28}$ This provision would normally block a federal court from conducting the sort of review mandated by the New York law. Accordingly, the Supreme Court was faced with the question of which rule would prevail in a diversity suit brought in a federal court in New York.

Justice Scalia, in dissent, took the jurispathic path, arguing categorically that federal courts must follow the Seventh Amendment's command regardless of what a New York court would do ${ }^{8} 3$ Thus, the New York law would have no impact at all in a federal diversity suit. In contrast, Justice Ginsburg worked hard to create a Solomonic solution whereby both New York's tort-reform interests and the Seventh Amendment could be accommodated.

To do this, Ginsburg construed the Seventh Amendment's Reexamination Clause to apply to federal appellate courts but not to the traditional power of federal trial judges to grant new trials notwithstanding a contrary jury verdict. ${ }^{8_{4}}$ Thus, she reasoned that New York's law controlling compensation awards for excessiveness or inadequacy could be given effect without detriment to the Seventh Amendment, if the review standard set out in the state statute were applied by the federal trial-court judge, with appellate control of the trial court's ruling confined to "abuse of discretion." ${ }_{55}$ Under this approach, the trial judge could apply state law reviewing the jury verdict, thereby retaining this state policy choice in state-law cases tried in federal courts, ${ }^{86}$ while the Seventh Amendment prohibition on reexamining jury verdicts would continue to bind the federal appellate court (absent a flagrant abuse of discretion) ${ }^{87}$

Whatever one thinks of the soundness of Ginsburg's historical and jurisprudential analysis, what is most significant is the extraordinarily creative way in which Ginsburg worked to accommodate both state and federal interests. Had the Court adopted Justice Scalia's approach, a litigant from outside New York involved in a state-law suit with a New Yorker would be able to avoid the state's tort-reform provision simply by filing that case in, or removing that case to, federal court. On the other hand, had the Court simply applied the state law without limitations, it would have been ignoring the significant command of the U.S. Constitution regarding the sanctity of jury verdicts. By splitting the 
difference, the Court arguably' protected the core of both state and federal interests at stake.

In Shady Grove Orthopedic Associates, P.A. v. Allstate Insurance Co., ${ }^{88}$ Ginsburg again sought to vindicate both state and federal interests in an Erie case. This time the question was whether, in a federal court, Rule 23 of the Federal Rules of Civil Procedure, governing class actions, would override another New York state law, this one aimed at preventing certain kinds of suits from being brought as class actions. Justice Scalia's plurality opinion took the jurispathic position that because the state law addressed class-action suits it was necessarily trumped by Rule 23 in cases heard in federal courts. ${ }^{89}$ Ginsburg, in dissent, chose a more nuanced reading. She took Scalia to task for "relentlessly" making choices that would override state law..$^{90}$ Instead, she pointed out - in true pluralist fashion - that "before undermining state legislation" the Court should ask whether the federal and state laws truly conflict.91 Thus, in contrast to the plurality opinion, she "would continue to interpret Federal Rules with awareness of, and sensitivity to, important state regulatory policies."92 Taking this approach, she read Rule 23 to dictate only the procedures for certifying and pursuing a class-action claim. In contrast, she argued, the New York state law addressed what sort of relief could be pursued through the class mechanism..$^{93}$ And, as with Gasperini, regardless of whether one agrees with her particular way of accommodating both federal and state law, there can be no doubting her passion to pursue an approach to Erie that attempts to provide maximum space for the effectuation of important state policy judgments.

Ginsburg's approach to federal preemption law seems to suggest the same impulse toward mutual accommodation and splitting the difference. For example, in American Airlines, Inc. v. Wolens, ${ }^{94}$ the question was whether the federal law deregulating the airline industry preempted state consumer-fraud and breach-of-contract claims brought against American Airlines related to changes the airline made unilaterally and retroactively to its frequent-flyer program. Two justices argued that federal law preempted both the fraud and contract claims, 95 while another argued that neither type of claim should be deemed preempted..$^{6}$ Ginsburg, writing for the Court, took the middle ground, holding that federal law preempted the fraud claims but not the contract claims. ${ }^{97}$ The Airline Deregulation Act explicitly preempted stateimposed regulation "relating to [air carrier] rates, routes, or services," 98 which would include consumer fraud claims based in state law. ${ }^{99}$ However, the contract claims, she concluded, were based not on state regulation but on claimed breaches of terms agreed upon by the parties themselves. Thus, they could be maintained without running afoul of the Airline Deregulation Act. ${ }^{100}$ 
In each of these cases, we see Ginsburg working mightily to make subtle distinctions so as to preserve space for both federal and state interests to be vindicated. Indeed, none of the conclusions she reached were clearly dictated by the cases, rules, or statutes Ginsburg interpreted. ${ }^{101}$ Thus, they are actually best understood as efforts to maintain a pluralist structure to American federalism, one that will allow sufficient play in the joints and overlapping jurisdiction so that all sovereignties are afforded an opportunity to weigh in with policy judgments. In short, understanding Ginsburg's pluralist jurisprudence creates a way of interpreting these cases as part of a broader approach to the interaction of legal systems.

\section{DEFERENCE TO INTERNATIONAL AND TRANSNATIONAL LAW AND PROCESS}

Of course, principles of deference are often easier in domestic cases because, although federalism opens up a wide range of structural pluralism, both state and federal governments sit within one constitutional system. This section turns to Justice Ginsburg's attitude toward foreign law as interpreted and applied by courts and tribunals from around the world. Here, Justice Ginsburg shows her willingness to learn from foreign judges, her interest in comparative examples, and her efforts to build deferential principles into cases with transnational implications. Yet, at the same time, Ginsburg believes that foreign law cannot displace core U.S. constitutional principles when U.S. officials act abroad. Thus, both foreign norms and U.S. norms operate in active relationship.

Ginsburg has long been interested in comparative law. As an academic, she attended multiple gatherings of the International Academy of Comparative Law. ${ }^{102}$ She also was affiliated with the Columbia Law School Project on International Procedure, was a member of the American Foreign Law Association, and served from 1964 to 1972 on the Board of Editors of the American Journal of Comparative Law. ${ }^{103}$ These experiences, she has stated, "powerfully influenced" her work as a lawyer, law professor, and judge. ${ }^{104}$

Perhaps for this reason, she often looks to foreign law in a way that emphasizes the ongoing interaction of legal systems in dialogue with each other:

My own view is simply this: If U.S. experience and decisions may be instructive to systems that have more recently instituted or invigorated judicial review for constitutionality, so too can we learn from others now engaged in measuring ordinary laws and executive actions against fundamental instruments of government and charters securing basic rights. ${ }^{105}$ 
Of course, as she recognizes, political, historical, and cultural contexts vary from country to country, and so the fit from system to system is imperfect. But that should not, she argues, "lead us to abandon the effort to learn what we can from the experience and wisdom foreign sources may convey." ${ }^{106}$

In 2011, Ginsburg went so far as to predict that the Supreme Court would over time more assiduously follow the lead of the Declaration of Independence by according "'a decent Respect to the Opinions of [Human]kind' as a matter of comity and in a spirit of humility."107 Note those two words: comity and humility. Both are core to Ginsburg's pluralist jurisprudence. By invoking comity, she recognized that "projects vital to our well being - combating international terrorism is a prime example - require trust and cooperation of nations the world over."1os And by focusing on humility, she suggested that legal systems should not see themselves as sealed off and unable to learn from the innovations that may exist elsewhere. ${ }^{109}$ Thus, judges may gain wisdom and learn from the experimentation of others. As I have argued elsewhere, this is one of the core reasons that pluralist processes may sometimes be preferable to more jurispathic approaches. ${ }^{10}$

Ginsburg's pluralist perspective regarding the need to accommodate foreign legal processes carries over to cases involving the interlocking day-to-day functions of courts transnationally. For example, in Intel Corp. v. Advanced Micro Devices, Inc., ${ }^{\text {"1 }}$ Ginsburg, writing for the Court, broadly interpreted a federal statute that permits a party in a foreign or international tribunal to seek discovery in federal district courts from persons subject to the federal courts' jurisdiction. Significantly, Ginsburg rejected the broad exception urged by Intel: that federal courts should not permit such discovery if the foreign court could not itself have obtained such discovery under its local laws. ${ }^{12}$ Instead, she reasoned that the foreign court's inability or refusal to order discovery itself says nothing about whether it would be happy to receive assistance from a U.S. court that is willing to do so."13 Thus, a blanket prohibition on such discovery might actually thwart the wishes of the foreign jurisdiction. ${ }^{114}$ Instead, she wrote, the best way to effectuate the aim of helping with the discovery needs of foreign jurisdictions is to permit (without requiring) such discovery, instead of imposing categorical limitations. "15 Of course, as in many Ginsburg opinions, she emphasized that district judges retain discretion to refuse or limit discovery based on a myriad of factors particular to each case. ${ }^{16}$ But she refused to place broad prohibitions on such intersystemic discovery and thereby cabin such case-by-case discretion. In the end, this approach allows both the foreign court and the U.S. court to engage in dialogue without categorical rules either requiring or preventing discovery.

Another key aspect of intersystemic interaction is the principle that one should not be able to evade local law simply by relocating. As shown earlier, 
Ginsburg is clear that, at least in the domestic context, there can be no broad public policy exceptions to the Full Faith and Credit Clause in order to prevent such evasion. But what about regulatory evasion in the transnational context, where there is no constitutionally mandated Full Faith and Credit Clause? This issue can arise if a litigant relocates abroad, but even more controversially when a U.S. governmental official acts abroad in ways that would be impermissible under the U.S. Constitution.

In this long-running debate about whether "the Constitution follows the flag," "ur Ginsburg has taken the position that U.S. officials cannot evade constitutional limitations by acting abroad rather than on U.S. soil. For example, in DKT Memorial Fund Ltd. v. Agency for International Development, she wrote: "Just as our flag carries its message ... both at home and abroad, so does our Constitution and the values it expresses." ${ }^{8}$ Accordingly, she concluded, "wherever the United States acts, it can only act in accordance with the limitations imposed by the Constitution." "19 Similarly, in United States v. Balsys, Ginsburg argued that "the Fifth Amendment privilege against self-incrimination prescribes a rule of conduct generally to be followed by our Nation's officialdom" and "should command the respect of United States interrogators, whether the prosecution reasonably feared by the examinee is domestic or foreign." ${ }^{20}$

Finally, it is significant that Ginsburg has cited, with approval, the intriguing decision in United States $v$. Tiede ${ }^{121}$ In Tiede, a foreign national accused of hijacking a Polish aircraft abroad was tried under German substantive law in Cold War Berlin in a court created by the United States. The U.S. court held that despite the use of German substantive law, the foreign national was entitled to a jury trial as a matter of U.S. constitutional right because the U.S. court must act in accordance with the Constitution even when situated beyond U.S. territorial borders. ${ }^{122}$ According to the court, "it is a first principle of American life - not only life at home but life abroad - that everything American public officials do is governed by, measured against, and must be authorized by the United States Constitution." ${ }^{123}$ Thus, Ginsburg appears to take very seriously the idea that the U.S. government is bound by the U.S. Constitution even beyond U.S. borders.

All of these different aspects of Ginsburg's transnational jurisprudence have a common theme: the desire to maintain a functioning global legal order characterized by respect among different systems, productive interaction among those systems, and the maintenance of cooperative efforts to cut off regulatory evasion while recognizing difference. These are core aspects of a pluralist cross-border jurisprudence. Indeed, Ginsburg's background as a comparative proceduralist make her perhaps the justice best positioned on the 
current Supreme Court to articulate how this sort of intersystemic perspective can work in day-to-day legal decisions.

\section{DEFERENCE TO TRIBAL COURTS}

In contrast to her approach to international and foreign law, Ginsburg does not appear to view tribal communities as true independent sovereignties, whose jurisdiction and legal rulings are intrinsically entitled to deference. Instead, Ginsburg, even as early as her Senate confirmation hearings, seems for the most part to have adopted the conventional view that tribes possess only the rights and privileges awarded to them by Congress. ${ }^{124}$ As a result, this appears to be one area of Ginsburg's intersystemic jurisprudence where the focus is not so much on dialogue among communities as on the determinative law of one sovereignty over another. This is not to say that the tribes always lose in Ginsburg's decisions, but to the extent the tribes are given zones of autonomy, they are given them as an artifact of congressional largess. Thus, there is little jurisgenerative dialogue among equal sovereigns; the historically hierarchical relationship has been left largely undisturbed.

It is reasonable to ask why Ginsburg does not seem to view tribes through her usual prism of deference to another sovereign community. And while we cannot know for sure, one prominent Indian law scholar, Carole Goldberg, has suggested that Ginsburg's uneasiness with tribal community-based claims may spring from her days at the ACLU advocating for women's rights. ${ }^{125}$ In the late 1970 s the national board of the ACLU considered what position it should take in a key case then pending before the Supreme Court, Santa Clara Pueblo v. Martinez. ${ }^{126}$ In this case, a female tribe member challenged a tribal law denying tribal membership to the children of women who married out of the Tribe, but granting membership to the children of men who married out. ${ }^{127}$ Accordingly, the case raised both an Indian law question about the rights of tribes to define their own membership and an equality question about the gender distinction contained in the tribal rule.

In a 2009 memoir, Indian law attorney Alvin Ziontz recalled a debate he had with Ginsburg, then director of the ACLU Women's Rights Project, regarding the position the ACLU should take on the case. According to Ziontz, for Ginsburg, "the equal protection issue clearly trumped any tribal interest."128 Based on Ziontz's account, Goldberg speculates that Ginsburg may have less sympathy for claims of tribal sovereignty because of concerns about potential gender discrimination in tribal communities. ${ }^{29}$

Turning to her actual jurisprudence on the Court, we see at times an unwillingness to treat the tribes in the generous way we saw her treat states in 
federalism cases. For example, in the 1997 case of Strate $v$. A-1 Contractors, ${ }^{130}$ Ginsburg wrote an opinion for the Court disallowing tribal court jurisdiction over a car accident on a state right-of-way in Indian country. To reach this conclusion, Ginsburg relied on an earlier Supreme Court case, lowa Mutual Insurance Co. v. LaPlante. ${ }^{31}$ However, as Goldberg points out, Iowa Mutual only denied tribal regulatory jurisdiction over non-Indians on non-Indian fee land within a reservation. ${ }^{132}$ Ginsburg thus was extending Iowa Mutual when she applied it to deny tribal adjudicative jurisdiction over a non-Indian on a state right-of-way on tribally owned land within a reservation. Moreover, Goldberg argues, "Neither the leap from regulatory to adjudicative jurisdiction, nor the leap from non-Indian fee land to a state right-of-way, was logically required or driven by congressional policy." ${ }^{33}$ Thus, the Court's decision in Strate cut back on tribal court jurisdiction and therefore the potential intersystemic interaction between tribal and state courts.

Even more controversial for some Indian law scholars was Ginsburg's decision in City of Sherrill v. Oneida Indian Nation of New York. ${ }^{34}$ This case derived from long-standing property claims of the Oneida, who signed a treaty with the United States after the Revolutionary War guaranteeing protection for 300,000 acres of land in upstate New York. ${ }^{35}$ Despite federal law that prevented alienation of the land without federal consent, ${ }^{136}$ the State of New York subsequently entered into several treaties with the Oneida that transferred almost all of this reservation land into private hands. ${ }^{37}$ At various times during the nineteenth and twentieth centuries, the Tribe tried to recover its land, but it was not until the 1970s that federal law allowed the Tribe to sue on its own in federal court. ${ }^{138}$ The Tribe sued for compensation for violation of its possessory rights, and in two previous suits the Supreme Court had ruled that there was federal jurisdiction over such a cause of action and that no statute of limitations defense could bar the suit. ${ }^{139}$

In 1997 and 1998 the Oneida purchased land that had been within its reservation originally and then claimed tribal sovereignty over the land, suing to enjoin the local government from imposing property taxes. ${ }^{44^{\circ}}$ Goldberg argues that "from an Indian law perspective, the question should have been relatively straightforward: was the reacquired Oneida land properly considered Indian country, within the meaning of the federal statute defining that term?" "141 If so, according to Goldberg, then the land could not be taxed absent express federal statutory authority. Moreover, federal law defines Indian country as all land within a reservation's boundaries, ${ }^{142}$ and relevant precedent holds that a reservation cannot be diminished absent federal permission. ${ }^{43}$ Thus, Goldberg contends that this newly reacquired land, because it was within the boundaries of the historical reservation (which 
had never legally been diminished), would qualify for tax-exempt treatment as Indian country.144

Justice Ginsburg's opinion for the Court, however, focused instead on the fact that the land in question had been in state control for two hundred years, even if it had originally been taken illegally. According to Ginsburg,

The wrongs of which [the Oneida Nation] complains occurred during the early years of the Republic, [whereas], [f]or the past two centuries, New York and its [local] units have continuously governed the territory.... This long lapse of time, during which the Oneidas did not seek to revive their sovereign control through equitable relief in court, and the attendant dramatic changes in the character of the properties, preclude [the Oneida Nation] from gaining the disruptive remedy it now seeks. ${ }^{145}$

Goldberg argues that by emphasizing the long lapse of time, the Court seems to penalize the tribe for not having had the funds to reacquire the land until recently. ${ }^{16}$ Moreover, the focus on time suggests to Goldberg a conception of the tribes as vestigial actors, not present-day sovereign entities. ${ }^{147}$ The Court describes the original alienation of the Oneida's land as a "grave, but ancient, wrong," 148 and the opinion uses the word "ancient" multiple times in the opinion. ${ }^{49}$ Goldberg argues that, by isolating the harm in the past, the Court "seems unwilling to acknowledge the ongoing struggles and survival of the Oneidas as a distinct people in contemporary America, and the ongoing nature of the wrongs that have been committed against them." 150

Despite these opinions, it is important to note that Ginsburg's Indian law jurisprudence is certainly not invariably hostile to tribal interests. For example, in Wagnon v. Prairie Band Potawatomi Nation, ${ }^{151}$ she dissented from a decision imposing state taxes on non-Indian distributors of motor fuel to onreservation gas stations. In her dissent, she went out of her way to clarify the sovereign interests at stake: "Kansas' collection of its tax on fuel destined for the Nation Station will effectively nullify the Nation's tax, which funds critical reservation road-building programs, endeavors not aided by state funds." ${ }^{152}$ Similarly, she largely dissented from the Court's decision in Plains Commerce Bank v. Long Family Land \& Cattle Co., ${ }^{153}$ which denied tribal court jurisdiction over a mortgage-discrimination suit brought by tribal members against a non-Indian bank. Ginsburg noted that the case was not, as the Court framed it, "about 'the sale of fee land on a tribal reservation by a non-Indian bank to non-Indian individuals."'154 Rather, she asserted, quoting the earlier Court of Appeals decision in the case: "this case is about the power of the Tribe to hold nonmembers like the bank to a minimum standard of fairness when they 
voluntarily deal with tribal members."'155 As Goldberg points out, the dissent also demonstrates sensitivity to the realities on the ground, "including the fact that Plains Commerce Bank often filed suit in tribal court to collect on its debts, benefited from the availability of [federal Bureau of Indian Affairs] loan guarantees, and could have included a choice-of-forum clause in its agreements had it wished to avoid tribal court."156 Thus, it would be unfair to say that Ginsburg is always hostile to tribes. On the other hand, the reflexive deference she accords other judicial systems does not seem to carry over to tribal courts and governmental institutions as a matter of course.

\section{CONCLUSION}

It is difficult, of course, to pick out a handful of cases from decades of jurisprudence in order to spot trends. And there is always the danger of cherry-picking those cases that seem to support a thesis while ignoring other decisions that might point in a different direction. Moreover, each case presents different facts and different substantive law contexts, making broad generalizations inherently problematic.

Nevertheless, a pronounced preference for legal pluralist approaches can be discerned in Ginsburg's scholarship and in her judicial opinions. When faced with questions involving the interaction of legal systems, Ginsburg often chooses a path that emphasizes mutual accommodation, deference, and the opportunity for different systems to pursue their processes and speak to an issue. Ginsburg eschews bright-line rules that close off avenues through which a system might be allowed to articulate its norms, and she bends over backward to seek Solomonic solutions that will effectuate multiple interests. In the international arena, she humbly seeks wisdom abroad, aims to accommodate foreign processes if possible, and makes sure U.S. officials abroad follow constitutional commands. All of these jurisprudential paths aim toward making the United States a partner in the world system, not a hierarchically dominant voice. And although she seems somewhat less accommodating in cases relating to tribal sovereignty, even here she has at times shown a willingness to try to defer to tribal jurisdictional claims.

Just as important, this analysis suggests that we can evaluate judicial opinions and philosophies through the lens of legal pluralism. This interpretive lens focuses less on substantive outcome or political labels such as liberal or conservative and more on the way in which the judge understands his or her role in an interlocking, multijurisdictional legal tapestry. And given that judges inevitably face questions involving the interaction of legal systems, we can legitimately ask how each judge seeks to navigate the hybrid 
spaces that result. Thus, a pluralist framework provides an untapped means of considering jurisprudential legacies. In the case of Justice Ginsburg, an emphasis on mechanisms for managing pluralism illuminates tendencies in her judicial approach that otherwise may have escaped notice. 